\title{
Symbolae Florae Bryophytae Orientali-Asiae et Micronesiae. IX.*
}

\author{
$\mathrm{By}$ \\ Yoshiwo Horikawa.
}

With 3 Text-figures.

Received January 1, 1936.

190) Plagiochasma intermedium Lindenberg et Gottsche in Gottsche, Lindenberg et Nees, Synop. Hepat. (1846) p. 513.

Syn. Rupinia intermedia Trevisan in Mem. R. Ist. Lomb. III. 4. (1877) p. 437.

Aytonia intermedia Underwood in Bot. Gaz. XX. (1895) p. 66.

Aitonia japonica Stephani in Bull. Herb. Boiss. V. (1897) p. 84.

Plagiochasma japonicum StePhani Sp. Hep. I. (1898) p. 777.

Nom. Jap.' Tsubo-zenigoke, Mikan-goke.

Hab. On the calcareous rocks.

Manchuria： Mt. Hêshangshan [和少山], prov. Kwangtung (Y. HorIKawa, July 20, 1935).

Distr. Mexico, China (prov. Shensi), Formosa, Japan Proper.

The species is a new addition to the flora of Manchuria.

191) Pellia Neesiana (Gottsche) Limpricht in Cohn Krypt. Fl. Schles. I. (1876) p. 329.

Syn. Pellia epiphylla f. Neesiana Gotтsche in Hedwigia (1867) p. 69.

Nom. Jap. Yezo-mizuzenigoke.

Hab. On wetty sandy soil.

Korea: Mt. Kongôzan, prov. Kôgen (Y. Horikawa, Aug. 5, 1935).

Distr. Europe, Himalaya, China, Formosa, Yakushima, Japan Proper, Quelpaert, Hokkaidô, Saghalien, North America.

This species is new to the flora of Korea.

192) Ptilidium pulcherrimum (Weber) Hampe Prod. Fl. Here. (1836) p. 76 .

Syn. Jungermannia pulcherrima WEBER Spicil. Fl. Götting. (1778) p. 150.

* The expense of the study has been partly defrayed by the Subsidy granted by the Foundation for the Promotion of Scientific and Industrial Research of Japan. 
Ptilidium ciliare $\beta$ Wallrothianum NeEs Eur. Leberm. III. (1838) p. 120.

Blepharozia pulcherrima Lindberg Musc. Scand. (1879) p. 5.

Ptilidium ciliare var. pulcherrimum WARnstorF Krypt. Fl. Mark Brand. (1902) p. 260.

Nom. Jap. Tegatagoke.

Hab. On the barks and decayed logs.

Korea: Mt. Hakutôzan, prov. Kanhoku (Y. Horikawa, Aug. 1, 1935).

Distr. Europe, Siberia, Quelpaert, Japan Proper, Saghalien, Alaska, North America.

The species is a new addition to the flora of Korea.

193) Jubula japonica Stephani in Bull. Herb. Boiss. V. (1897) p. 92.

Nom. Jap. Hime-urushigoke.

Hab. On the decaying logs.

Formosa: Mt. Daijurin, prov. Takao (Y. Horikawa, Jan. 4, 1935).

Distr. Hokkaidô, Japan Proper, Quelpaert, Yakushima, Liukius.

This species is new to the flora of Formosa and the island seems surely to be the southern limit place in its distribution.

194) Microlejeunea ponapensis Horikawa, sp. nov.

Dioica, exigua, pallide flavicans, ad $8 \mathrm{~mm}$ longa, cum foliis $0.4 \mathrm{~mm}$ lata, foliicola. Caulis ca. $0.013 \mathrm{~mm}$ in diametro, irregulariter longeque ramosus. Folia caulina remota, oblique patula (ca. $45^{\circ}$ ), parum concava, ambitu oblongo-elliptica, asymmetrica, ca. $0.26 \mathrm{~mm}$ longa, $0.12 \mathrm{~mm}$ lata, apice acuta, lata basi inserta, basi antica brevissima truncata. Cellulae folii ubique fere aequales, medio ca. $19 \mu$ in diam., trigonis nullis. Lobulus magnus (saepe obsoletus), folio duplo brevior, ca. $0.13 \mathrm{~mm}$ longa, $0.083 \mathrm{~mm}$ lata, inflatus ovoideus, carina oblique adscendens, valde arcuata, substricte in folium excurrens, apice quam basis subtriplo angustiore, leviter exciso, angululo subacuto. Amphigastria caulina exigua, cauli aequilata vel parum minora, ambitu subrotunda, basi 3 cellulas lata, transverse inserta, ad medium bifida, sinu amplo, segmentis 1-2 cellulas longis, subobtusis. Perianthia uno latere innovata, pyriformia, ea. $0.5 \mathrm{~mm}$ longa et $0.3 \mathrm{~mm}$ lata, quinqueplicata, plicis acutis levibus, apice truncata, rostro parvo. Folia floralia perianthio triplo breviora, obovato-oblonga, apice acuminata; lobulus parum brevior, valde angustus lanceolatus, ad 1/3 solutus, acuminatus, amphigastrio connatus. Amphigastrium florale lobulis aequilongum, triangulato-lanceolatum, acutum, integerrimum. Androecia ignota.

Hab. On the leaves of Eugenia stelechantha.

Micronesia: Mt. Troton, isl. Ponape, East Caroline (T. Hosokawa, Aug. 


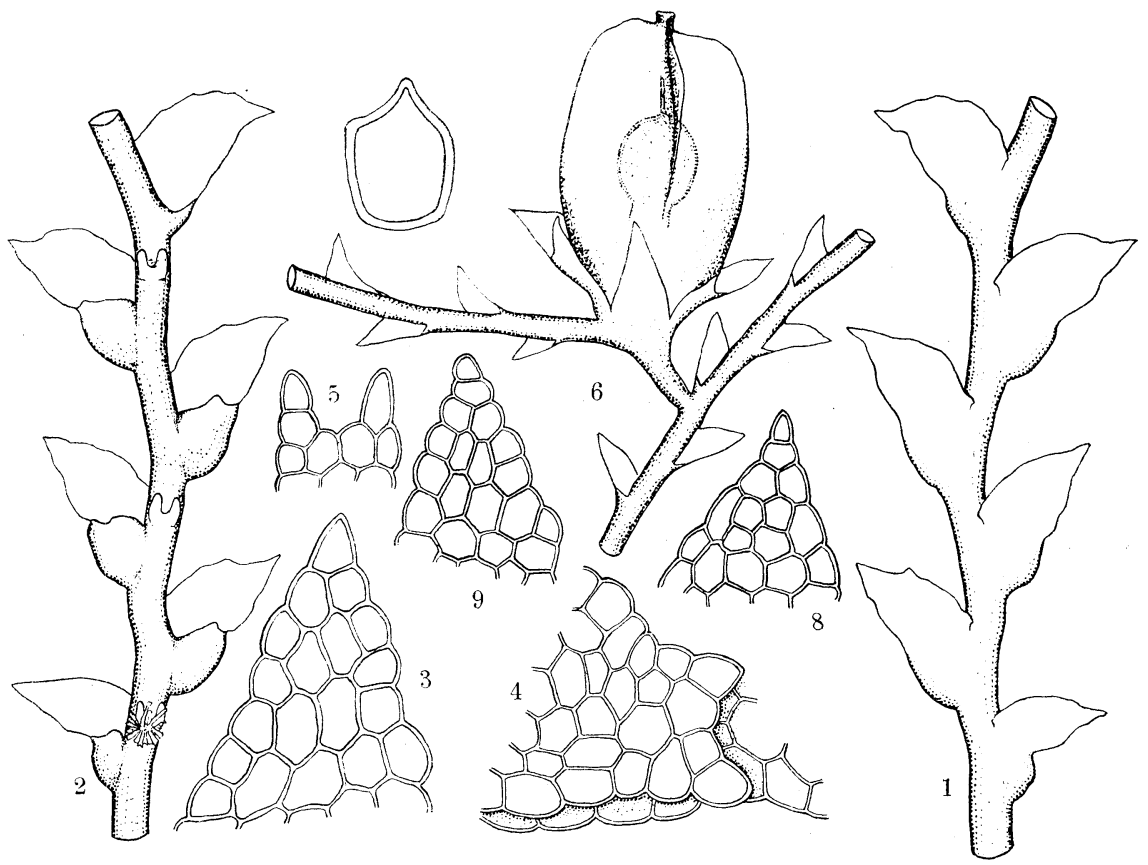

Text-fig. 33. Microlejeunea ponapensis Horikaws. 1. Part of stem, antical view, $\times 78$. 2. Ditto, postical view, $\times 78$. 3. Upper half of leaf, $\times 330$. 4. Apical part of lobule, $\times 330$. 5. Underleaf, $\times 330$. 6. Part of branches with perianth, postical view, $\times 78$. 7. Cross-section of perianth, $\times 60$. 8 . Upper half of involucral bract, $\times 280$. 9. Upper half of bracteole, $\times 280$.

$13,1933)$.

The shape of the bracteole will at once separate this species from all the representatives of the genus Microlejeunea; it is triangular-lanceolate in outline and its apex being subobtuse, neither bilobed nor emarginate.

195) Orthomnium curiosissimum Horikawa, sp. nov.

Robustum, caespitosum, viridibus, nitidis, stolonibus elongatis, repentibus, per totam longitudinem dense fusco-radiculosis, superne densiuscule foliosis. Folia sicca vix contracta, humida patula, planiuscula, haud decurrentia, e basi brevissima, comalia spathulata, obtusissima vel apiculata, ca. $5 \mathrm{~mm}$ longa et $3 \mathrm{~mm}$ lata, marginibus erectis, integris, limbata, limbo lutescente, angustissimo, ex unica serie cellularum elongatarum formato, nervo basi lato, superne multo angustiore, infra summum apicem evanido, bus, per totam longitudinem dense fusco-radiculosis, superne densiuscule in sectione transversali biconvexo, postice pro more magis producta, fasciculo comitum et fasciculo stereidearum nullo, cellulis ovalihexagonis, in parte superiore laminae ca. $52 \times 63 \mu$ in diam., basim versus sensim 
majoribus, in parte infima folii elongate rectangularibus, omnibus plus minusve chlorophyllosis, laevissimis. Caetera desunt.

Hab. On the barks of trees. Formosa: Mt. Taiheizan (Toganoo), prov. Taihoku (Y. Horikawa, Aug. 23, 1932).

Of four species, the present species is near to $O$. Loheri BRoTh. ${ }^{1)}$ and $O$. stolonaceum BRotri., ${ }^{2)}$ both of which have known from the Philippines, by the nerve ceasing far below the leaf-

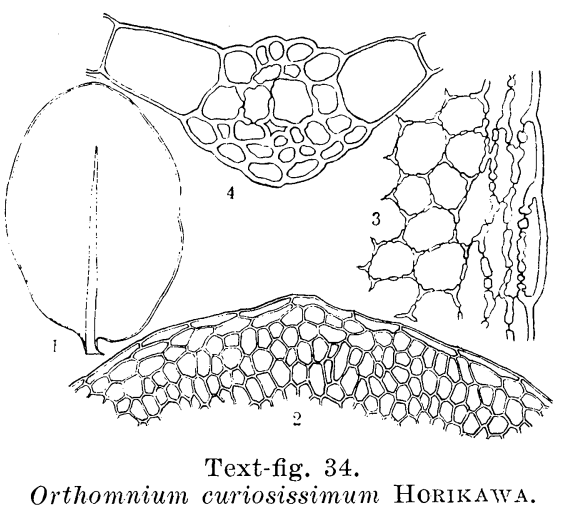

1. Leaf, $\times 9$.

2. Apical part of leaf, $\times 78$.

3. Marginal part of leaf, $\times 170$.

4. Cross-section of leaf, $\times 280$. apex, but differs essentially in the structure of midrib, and usually in the shape of leaves and the pitted leaf-cells. The genus Orthomnium is also a new addition to the flora of Japanese Territory.

196) Mnium affine Blandow Mues. frond. exs. fase. III. (1804) p. 133. var. elatum Bruch et Schimper Bryol. eur. IV. (1836-51) Mnium p. 31.

Syn. Mnium Seligeri Juratzka ; Milde Bryol. siles. (1869) p. 227.

Astrophyllum Seligeri Lindierg Muse. scand. (1879) p. 14.

Nom. Jap. Seitaka-karakusagoke.

Hab. On damp soil in woods.

Korea: Mt. Hakutôzan, prov. Kanhoku (Y. HonIkawa, Aug. 1, 1935).

Honshiu: Kamikôchi, prov. Shinano (Y. Horikawa, July 7, 1935).

Distr. Europe, Caucasus, Himalaya, Siberia, Hokkaidô, North America.

This variety is a new addition to the floras of Korea and Japan Proper.

197) Mnium Thomsoni Schimper Synop. ed. 2. (1876) p. 485.

Syn. Mnium lycopodioides (non Hooker) Mrtten in Journ. Proc. Linn. Soc. Bot. III. Suppl. (1859) p. 142.

Nom. Jap. Hime-chôchingoke.

Hab. On moist soil in woods.

Korea: Mt. Hakutôzan, prov. Kanhoku (Y. Horikawa, Aug. 1, 1935).

Distr. Nepal, Sikkim, Tibet, Yunnan, Liukius, Japan Proper, Hokkaidô.

1) Över. Finsk. Vet-Soc. Förhandl. XLVII, No. 14 (1904) p. 6.

2) The Philippine Journ. Sci. III. No. 1, Sect. C. Bot. (1908) p. 20. 
The species is new to the flora of Korea.

198) Pseudospiridentopsis horrida (Mitten) Fleischer Musc. Fl. Buitenzorg, III. (1906) p. 730.

Syn. Meteorium horridum Mitren.

Nom. Jap. Onigoke.

Hab. On the old trunks mixed with Plagiochila pulcherrima HorIKAWA.

Yakushima: Ishizuka-kokuyûrin (ca. 850 m., Y. Horikawa, July 11, 1933).

Distr. Bhutan, Philippines, Formosa.

This monotypic and splendid one is new to the flora of Yakushima, the island seems to be the locality of southern limit in its distribution.

199) Pterobryum subarbuscuia Brotherus in Över. Finska Vet. Soc. Förh. LXII. (1919-20) p. 22.

Nom. Jap. Taiwan-himurogoke.

Hab. On the old trunks.

Yakushima: Between Tashirobashi and Kosugidani (Y. Horikawa, July 9, 1033); Between Ishizukakokuyurin and Hananoego (Y. Horikawa, July 11, 1933) ; Between Hananoego and Daidôsugi (Y. Horikawa, July 12, 1933).

Distr. Formosa.

The present species is a new addition to the flora of Yakushima.

200) Hookeria acutifolia Hooker in Schwaegrichen Suppl. II, p. II, I. (1826) p. 36.

Syn. Hookeria Grevilleana GRIFFIth Notul. p. 473 et Icon. pl. asiat. (1849) pl. 2.

Pterygophyllum acutifolium BecherelLe Fl. bryol. Antill. fr. (1876) p. 53.

Nom. Jap. Taiwan-aburagoke (nov.)

Hab. On damp ground.

Formosa: Mt. Taiheizan (Kiyanrawazawa), prov. Taihoku (Y. Horikawa, Aug. 24, 1932); Mt. Arisan (Numanohira), prov. Tainan (Y. Horikawa, Aug. 18, 1932); Mt. Morrison (Kodamayama), prov. Tainan (Y. Horikawa, Aug. 18, 1932) ; Mt. Toranzan, prov. Taitô (Y. Horikawa, Jan. 7, 1935); Mt. Chipon, prov. Taitô (Y. Horikawa, Dec. 30, 1932); Mt. Daijurin, prov. Takao (Y. Horikawa, Jan. 4, 1935).

Distr. Nepal, Sikkim, Ceylon, Java, South America

This beautiful species is a new addition to the flora of Eastern Asia. 


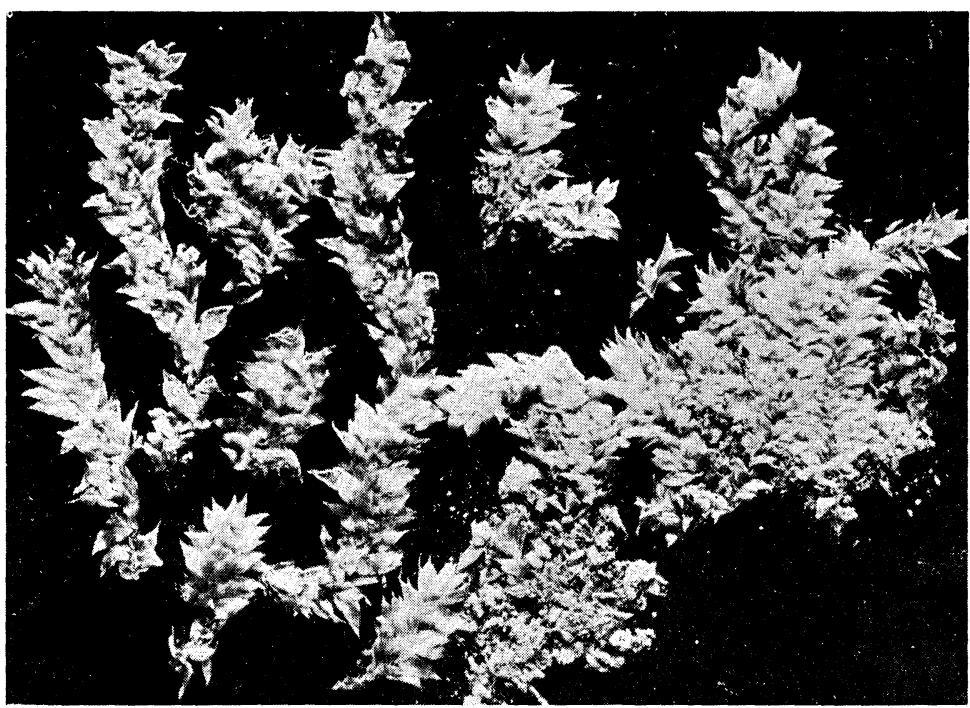

Text-fig. 35. Hookeria acutifolia Hooker, in natural size.

201) Catharinaea undulata (Linné) Weber et MoHr Ind. pl. crypt. (1803) et Bridel Bryol. univ. II. (1827) p. 102.

Syn. Bryum undulatum Linné Spec. pl. II. (1753) p. 117.

Polytrichum undulatum Hedwig Fund. II. (1782) p. 90.

Atrichum undulatum P. Beauv. Prodr. (1805) p. 42.

Nom. Jap. Namigata-tachigoke.

Hab. On moist soil in open woods.

Formosa: Mt. Morrison (Hattsûkwan-Taikwan-Tonbo), prov. Taichû (Y. Horikawa, Aug. 21, 1932).

Distr. Europe, Caucasus, Persia, Asia minor, Algeria, Madeira, Azores, Cochin China, China, Manchuria, Korea, Japan Proper. Hokkaidô, North America.

The species is a new addition to the flora of Formosa.

(To be continued.) 